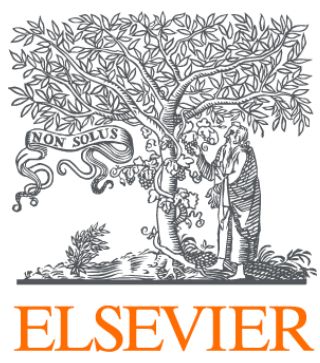

Since January 2020 Elsevier has created a COVID-19 resource centre with free information in English and Mandarin on the novel coronavirus COVID-

19. The COVID-19 resource centre is hosted on Elsevier Connect, the company's public news and information website.

Elsevier hereby grants permission to make all its COVID-19-related research that is available on the COVID-19 resource centre - including this research content - immediately available in PubMed Central and other publicly funded repositories, such as the WHO COVID database with rights for unrestricted research re-use and analyses in any form or by any means with acknowledgement of the original source. These permissions are granted for free by Elsevier for as long as the COVID-19 resource centre remains active. 


\title{
The association between air pollution and COVID-19 related mortality in Santiago, Chile: A daily time series analysis
}

\author{
Robert Dales $^{\mathrm{a}, \mathrm{e}}$, Claudia Blanco-Vidal ${ }^{\mathrm{b}}$, Rafael Romero-Meza ${ }^{\mathrm{c}}$, Stephanie Schoen ${ }^{\mathrm{d}}$, \\ Anna Lukina ${ }^{a}$, Sabit Cakmak ${ }^{\text {a,* }}$ \\ ${ }^{a}$ Population Studies Division, Environmental Health Science \& Research Bureau, Health Canada, Canada \\ ${ }^{\mathrm{b}}$ Pontifical Catholic University of Chile, Santiago, Chile \\ ${ }^{\mathrm{c}}$ School of Economics and Business, Universidad Alberto Hurtado, Santiago, Chile \\ ${ }^{\mathrm{d}}$ Public Health Agency of Canada, Ottawa, Canada \\ ${ }^{\mathrm{e}}$ University of Ottawa and Ottawa Hospital Research Institute, Ottawa, Canada
}

\section{A R T I C L E I N F O}

\section{Keywords:}

Chile

$\mathrm{O}_{3}$

$\mathrm{NO}_{2}$

$\mathrm{SO}_{2}$
$\mathrm{CO}$

$\mathrm{PM}_{10}$ and $\mathrm{PM}_{2.5}$, COVID-19

Mortality

Human health

Epidemiology

\begin{abstract}
A B S T R A C T
Background: Exposure to ambient air pollution is a risk factor for morbidity and mortality from lung and heart disease.

Research question: Does short term exposure to ambient air pollution influence COVID-19 related mortality? Study design and methodology: Using time series analyses we tested the association between daily changes in air pollution measured by stationary monitors in and around Santiago, Chile and deaths from laboratory confirmed or suspected COVID-19 between March 16 and August 31, 2020. Results were adjusted for temporal trends, temperature and humidity, and stratified by age and sex.

Results: There were 10,069 COVID-19 related deaths of which 7659 were laboratory confirmed. Using distributed lags, the cumulative relative risk (RR) $(95 \% \mathrm{CI})$ of mortality for an interquartile range (IQR) increase in $\mathrm{CO}, \mathrm{NO}_{2}$ and $\mathrm{PM}_{2.5}$ were 1.061 (1.033-1.089), 1.067 (1.023-1.103) and 1.058 (1.034-1.082), respectively There were no significant differences in RR by sex.. In those at least 85 years old, an IQR increase in $\mathrm{NO}_{2}$ was associated with a $12.7 \%$ (95\% CI 4.2-22.2) increase in daily mortality.

Conclusion: This study provides evidence that daily increases in air pollution increase the risk of dying from COVID-19, especially in the elderly.
\end{abstract}

\section{Introduction}

The current and unexpected outbreak of coronavirus disease 2019 (COVID-19) caused by SARS-CoV-2 virus rapidly spread around the world affecting almost all countries. The World Health Organization (WHO) declared COVID-19 a public health emergency of international concern on March 11th, 2020 and many countries put in place strict lockdowns. As of March 19th, 2021, there were over 121 million confirmed cases and over a two million deaths worldwide (WHO, 2021).

Risk factors for mortality from this novel coronavirus include older age, obesity, being immunocompromised, and pre-existing chronic health conditions (Noor and Islam, 2020; Simonnet et al., 2020). Among 72,314 confirmed cases in mainland China, case fatality rates (CFR) were higher among those with hypertension, diabetes, and chronic cardiac and pulmonary disease (Wu and McGoogan, 2020).

Globally, outdoor ambient air pollution is reported to be responsible for approximately 4.9 million premature deaths annually (Health Canada, 2019), and recent evidence suggests that air quality may adversely affect COVID-19 related outcomes. Several studies have reported that cities or regions with higher ambient air pollution have higher rates of infection, hospitalization and mortality from COVID-19 (Copat et al., 2020). These spatial associations could be influenced by differences between geographic areas in population density (Copiello and Grillenzoni, 2020), which is associated with both increased COVID-19 dissemination and air pollution levels. Differences in age, socioeconomic status and access to health care may also be potentially confounding factors. It has been reported that marginalized communities may be more affected by the pandemic (Anderson et al., 2020), and

\footnotetext{
* Corresponding author. Population Studies Division, Environmental Health Science \& Research Bureau, Health Canada, 101 Tunney’s Pasture Driveway, Ottawa, ON, K1A 0K9, Canada.

E-mail address: sabit.cakmak@canada.ca (S. Cakmak).
} 
some studies omit to include such co-factors (Zhu et al., 2020; Fattorini and Regoli, 2020).

Studies of temporal associations between air pollution and COVID-19 have certain advantages over testing for spatial associations. An advantage of time series analysis is that it can be used to test the associations between daily changes in air pollution and daily changes in health in the same population; thus, addressing any potential confounding by population density, social status or the prevalence of underlying health conditions that are constant over months or years. Very few such studies of air quality and COVID-19 related mortality have been published and results have been conflicting. Yao et al. (2020a) reported that the daily COVID-19 case fatality rate in China increased by just under $1 \%$ for a $10 \mu \mathrm{g} / \mathrm{m}^{3}$ increase in $\mathrm{PM}_{2.5}$ and $\mathrm{PM}_{10}$, with values of $0.86 \%(0.50 \%-1.22 \%)$ and $0.83 \%(0.49 \%-1.17 \%)$, respectively. Zoran et al. (2020a, 2020b) found that COVID-19 related deaths in Milan significantly decreased on days withhigher concentrations of $\mathrm{NO}_{2}(\mathrm{r}=$ $-0.58)$ and $\mathrm{PM}_{2.5}(\mathrm{r}=-0.53)$, and increased on days of higher $\mathrm{O}_{3}$ levels $(r=0.69)$. A New York based study using time series analysis methods also reported that COVID-19 related mortality was unexpectedly lower on days of higher $\mathrm{O}_{3}$ and $\mathrm{PM}_{2.5}(\mathrm{p}<0.05)$. Regression model estimates using a moving average lag of 0-21 days, and adjusted for trend and weather were -0.115 (SE: 0.057) and -0.110 (SE: 0.053) for $\mathrm{O}_{3}$ and $\mathrm{PM}_{2.5}$, respectively, both significant at $\mathrm{p}<0.05$ (Adhikari and Yin, 2020).
The objective of the present study is to determine the associations between daily changes in ambient air pollution and mortality from COVID-19 in Santiago, Chile between March and August 2020, adjusting for unwanted temporal trends, day of the week, temperature, and humidity. The first COVID-19 related cases in Chile were detected in early March 2020, but continued to increase exponentially through time (Bolano-Ortiz et al., 2020). Despite early government implemented interventions, as of November 18th, 2020, 533,661 confirmed cases and 14,883 mortality cases had been recorded in Chile (WHO, 2020). Prior to the COVID-19 pandemic, Santiago, Chile, with a population of 6.3 million people (Bolano-Ortiz et al., 2020), had relatively high concentrations of ambient air pollutants (WHO, 2016), and historically has exceeded ambient air pollution levels in most European and North American cities (Kavouras et al., 2001; Jorquera et al., 2004).

\section{Methods}

\subsection{Air quality data}

This study included the population living within the 32 communas of the Province of Santiago, Chile(Santiago Province in Chile, 2020) and two adjacent urban communas (i.e., Puente Alto, and San Bernardo) (Fig. 1). The communas are grouped into nine sectors, each with a stationary air quality monitor measuring ambient air pollutant

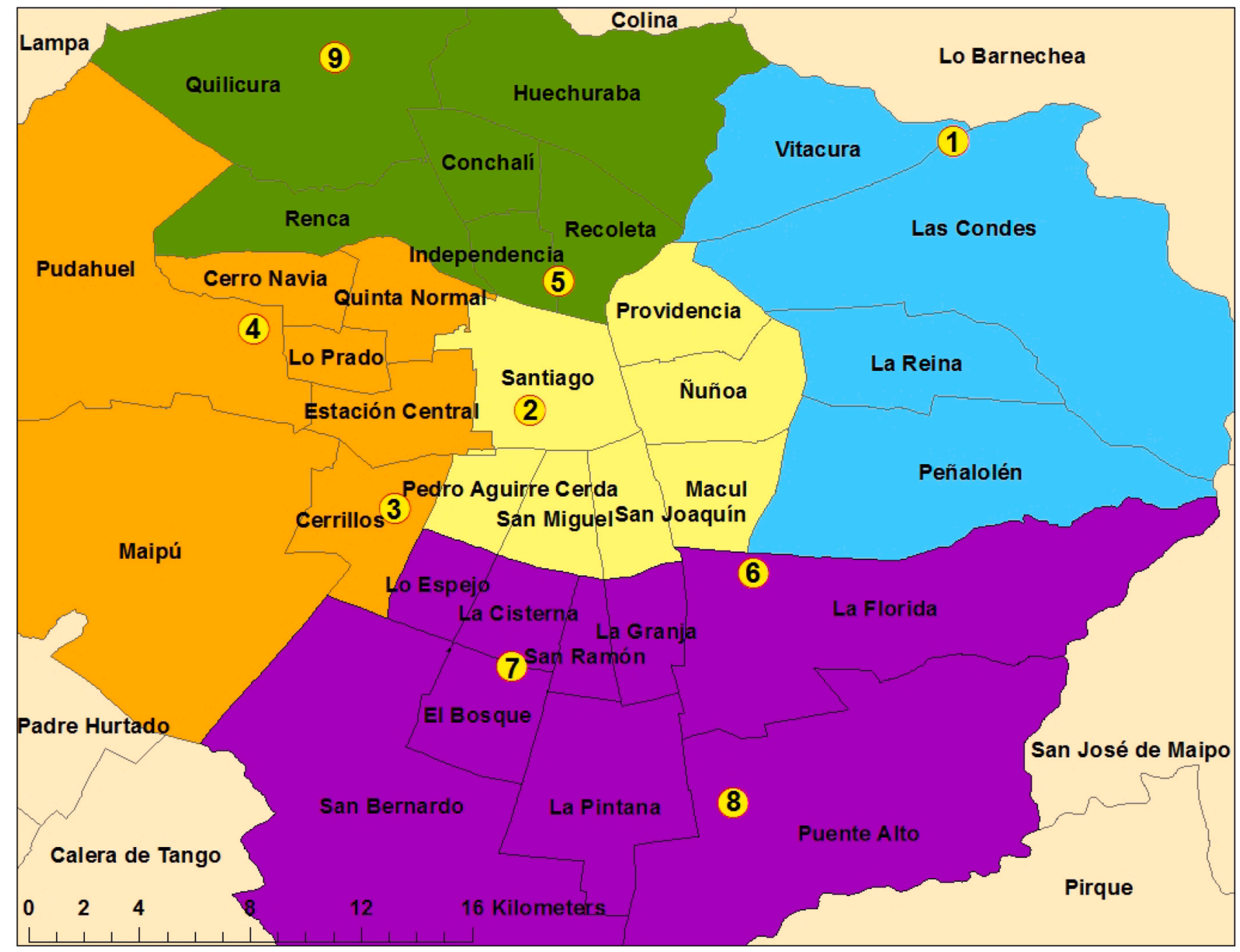

Fig. 1. Map of Santiago, Chile where air pollution and meteorological conditions were collected from nine stations: 1) Las Condes, 2) Parque O’Higgins, 3) Cerrillos, 4) Pudahuel, 5) Independencia, 6) La Florida, 7) El Bosque, 8) Puente Alto, 9) Quilicura. (Ministry of Environment, Chile). 
concentrations (Table 1). The nine sectors are Cerrillos, El Bosque, Independencia, La Florida, Las Condes, Parque O'Higgins, Pudahuel, Puente Alto, and Quilicura. For the Cerillos and Quilicura communes, only $\mathrm{PM}_{2.5}$ measures were available. Available climate data included 24-h mean temperature and relative humidity. Mortality cases were assigned the air pollution and weather variables measured within their sector of residence.

\subsection{Mortality data}

We used daily data collected by the Chilean Statistical Institution and provided by the Ministry of Environment of Chile for March 16th through August 31st, 2020. According to the International Classification of Disease, 10th Revision (ICD-10) (WHO, 2019), a laboratory confirmed diagnosis of COVID-19 is coded as U07.1. U07.2 is "assigned to a clinical or epidemiological diagnosis of COVID-19, where laboratory confirmation is inconclusive or not available." Both U07.1 and U07.2 may be used for mortality coding as a cause of death. For the purposes of this study, we refer to U07.1 as confirmed and U07.2 as presumed, and the two together as COVID-19 related mortality.

\subsection{Statistical Analyses}

Time series analyses were used to test the associations between dayto-day changes in air pollution and day-to-day changes in COVID-19 mortality. A two-stage random effects model for count data as in Cakmak et al. (2007), which assumes a Poisson distribution of daily deaths, was used. In the first stage, sector-specific daily variations in the number of deaths were related to daily variations in ambient air pollutant concentrations using generalized additive models as often applied in multi-center time-series studies (Samoli et al., 2005). In the second stage, the results were pooled using a random effects model (DerSimonian and Nan, 1986).

For each sector we adjusted daily mortality for unwanted temporal trends by using natural nonparametric splines and tested knots for every $15,30,45$ and 60 days of observation. The predicted model was selected based on minimization of the Akaike information criterion (AIC, a measure of model prediction) and on evidence that the model residuals did not display any type of structure, including serial correlation, using Bartlett's test. The model was adjusted for day-of-the-week using an indicator variable. Having selected the optimal model for time, using step-wise backwards and forwards regressions, we then tested 24-h mean temperature and humidity for inclusion in the model while keeping the variables for time and day-of-the-week constant. We tested the effect of air pollution measured on the day of mortality and also the cumulative effect of daily air pollution concentrations measured on the day of death and the moving daily average of the previous 6 days using unconstrained distributed lags as described by Schwartz (2000). We did not adjust for age, sex, social status, or population density, which are considered time invariant over the time of the study. Results were expressed as an increase in relative risk (RR) of COVID-19 mortality for an interquartile increase in each ambient pollutant. The interquartile range (IQR), the middle fifty-percent of the exposure range, provides a realistic estimate of the normal day-to-day changes in air pollution, from somewhat low to somewhat high. Being nonparametric it naturally excludes extreme values, making it resistant to the influence of skewed data. The pooled results for overall population, and stratified by sex and age group (i.e., $<65,65-74,75-84,>84$ years) are reported.

We performed a sensitivity analysis to explore the independent effects of pollutants. The effect of each pollutant of interest was tested while adjusting for each of the other pollutants in two-pollutant models.

\section{Results}

Between March and August 2020, there were a total of 10,069 COVID-19 related deaths in Santiago, Chile of which 7659 were laboratory confirmed. The median age was 76 years old and $43 \%$ were female. Combined, communas had an average of 109.45 daily COVID-19 related deaths. Mean air pollution concentrations were $0.73 \mathrm{ppm}$ (IQR $=0.43$ ) for carbon monoxide (CO), $19.89 \mathrm{ppb}(\mathrm{IQR}=9.69)$ for nitrogen dioxide $\left(\mathrm{NO}_{2}\right), 14.21 \mathrm{ppb}(\mathrm{IQR}=9.42)$ for ozone $\left(\mathrm{O}_{3}\right)$ and $29.78 \mu \mathrm{g} / \mathrm{m}^{3}$ $(\mathrm{IQR}=18.39)$ for particulate matter with particle diameter less than 2.5 $\mu \mathrm{m}\left(\mathrm{PM}_{2.5}\right)$ (Table 1). Strong positive correlations $(\mathrm{r} \geq 0.6)$ were found between $\mathrm{CO}, \mathrm{NO}_{2}$ and $\mathrm{PM}_{2.5} \cdot \mathrm{O}_{3}$ was negatively but not strongly correlated with the other pollutants (Table 2 ).

There was an approximate $6 \%$ increase in daily deaths from COVID19 related mortality for an IQR increase in $\mathrm{CO}, \mathrm{NO}_{2}$ and $\mathrm{PM}_{2.5}$, using distributive lags, with cumulative RR estimates $(95 \% \mathrm{CI})$ of 1.061 (1.033-1.089), 1.067 (1.023-1.103) and 1.058 (1.034-1.082), respectively (Table 3). There was no significant overall effect of $\mathrm{O}_{3}$ (Table 3 ). To test the sensitivity of the results to the lag structure used, we also calculated lag 0 effects. Estimates were very similar to those using distributed lags with respective $\mathrm{RR}(95 \% \mathrm{CI})$ for $\mathrm{CO}, \mathrm{NO}_{2}, \mathrm{PM}_{2.5}$, and $\mathrm{O}_{3}$ of 1.058 (1.031-1.085), 1.063 (1.029-1.098), 1.061 (1.036-1.085), and for $03,0.958$ (0.903-1.017). No sex-related differences were observed.

Table 2

Minimum and maximum Spearman correlation coefficients between air pollutants for the nine sectors.

\begin{tabular}{lllll}
\hline Pollutant & Correlation & $\mathrm{NO}_{2}$ & $\mathrm{O}_{3}$ & $\mathrm{PM}_{2.5}$ \\
\hline $\mathrm{CO}$ & minimum & 0.79 & -0.42 & 0.65 \\
& maximum & 0.83 & -0.26 & 0.81 \\
$\mathrm{NO}_{2}$ & minimum & & -0.29 & 0.64 \\
& maximum & & -0.13 & 0.72 \\
$\mathrm{O}_{3}$ & minimum & & & -0.21 \\
& maximum & & & -0.10 \\
\hline
\end{tabular}

Table 1

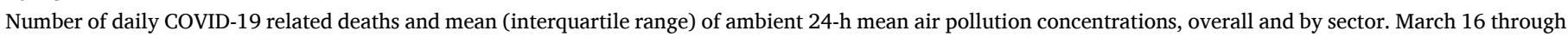
August 31, 2020.

\begin{tabular}{|c|c|c|c|c|c|c|}
\hline \multirow[t]{2}{*}{ Sector } & \multirow[t]{2}{*}{ Population } & \multirow{2}{*}{$\frac{\text { Mean Deaths }}{\text { [daily] }}$} & \multirow{2}{*}{$\frac{\mathrm{CO}}{[\mathrm{ppm}]}$} & \multirow{2}{*}{$\frac{\mathrm{NO}_{2}}{[\mathrm{ppb}]}$} & \multirow{2}{*}{$\frac{\mathrm{O}_{3}}{[\mathrm{ppb}]}$} & \multirow{2}{*}{$\frac{\mathrm{PM}_{2.5}}{[\mu \mathrm{g} / \mathrm{m} 3]}$} \\
\hline & & & & & & \\
\hline 1) Cerrillos & 85,026 & 16.24 & $\mathrm{n} / \mathrm{a}$ & $\mathrm{n} / \mathrm{a}$ & $\mathrm{n} / \mathrm{a}$ & $36.43(22.0)$ \\
\hline 2) El Bosque & 170,801 & 19.40 & $0.90(0.56)$ & $27.79(12.26)$ & $9.78(10.0)$ & $36.30(22.0)$ \\
\hline 3) Independencia & 105,437 & 13.18 & $0.79(0.40)$ & $6.94(2.81)$ & $9.74(10.0)$ & $28.70(16.5)$ \\
\hline 4) La Florida & 386,307 & 15.97 & $0.80(0.38)$ & 26.0 (11.39) & $24.71(6.0)$ & $27.05(15.0)$ \\
\hline 5) Las Condes & 307,708 & 7.20 & $0.44(0.19)$ & $21.01(11.04)$ & $16.33(10.5)$ & $17.78(12.0)$ \\
\hline 6) Pudahuel & 240,958 & 14.57 & $0.90(0.77)$ & $16.44(6.93)$ & $10.96(10.0)$ & $35.66(26.5)$ \\
\hline 7) Puente Alto ${ }^{a}$ & 568,094 & 8.80 & $0.61(0.33)$ & $14.48(10.59)$ & $13.73(10.0)$ & $27.09(14.0)$ \\
\hline 8) Quilicura & 222,048 & 2.25 & $\mathrm{n} / \mathrm{a}$ & $\mathrm{n} / \mathrm{a}$ & $\mathrm{n} / \mathrm{a}$ & $30.80(18.5)$ \\
\hline 9) Parque ÓHiggins & 446,490 & 11.84 & $0.64(0.41)$ & $26.58(12.83)$ & $36.43(22.0)$ & $28.23(19.0)$ \\
\hline Overall & & 109.45 & $0.73(0.43)$ & $19.89(9.69)$ & $14.21(9.42)$ & 29.78 (18.39) \\
\hline
\end{tabular}

Note: $\mathrm{n} / \mathrm{a}$ : pollution was not available at that location.

The population is based on 2017 Chile Population and Housing Census conducted in April 2017 (Census data for Santiago Province of Chile, 2020). 
Table 3

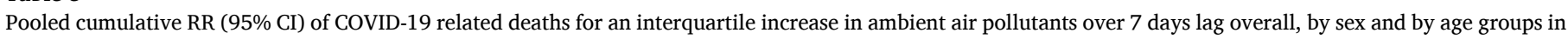

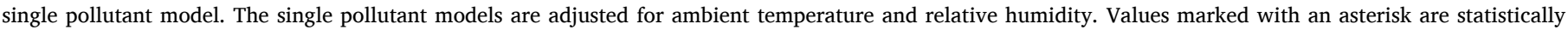
significant $(\mathrm{p}<0.05)$.

\begin{tabular}{|c|c|c|c|c|c|c|}
\hline & & \multirow[t]{2}{*}{$\mathrm{n}$} & \multirow[t]{2}{*}{$\mathrm{CO}$} & Pollutant & \multirow[t]{2}{*}{$\mathrm{O}_{3}$} & \multirow[t]{2}{*}{$\mathrm{PM}_{2.5}$} \\
\hline & & & & $\mathrm{NO}_{2}$ & & \\
\hline \multicolumn{2}{|l|}{ Overall } & 10,069 & $1.061(1.033,1.089)^{*}$ & $1.067(1.032,1.103)^{*}$ & $0.962(0.904,1.025)$ & $1.058(1.034,1.082)^{*}$ \\
\hline \multirow[t]{2}{*}{ Sex } & Male & 5718 & $1.071(1.035,1.11)^{*}$ & $1.064(1.017,1.112)^{*}$ & $0.938(0.862,1.02)$ & $1.059(1.027,1.091) *$ \\
\hline & Female & 4351 & $1.042(1.001,1.084)^{*}$ & $1.067(1.015,1.123)^{*}$ & $0.995(0.906,1.092)$ & $1.058(1.022,1.095) *$ \\
\hline \multirow[t]{4}{*}{ Age (years) } & $<65$ & 2476 & $1.033(0.983,1.085)$ & $1.018(0.956,1.085)$ & $1.04(0.926,1.169)$ & $1.05(1.006,1.096)^{*}$ \\
\hline & $65-74$ & 2771 & $1.063(1.011,1.117)^{*}$ & $1.022(0.958,1.09)$ & $0.739(0.656,0.832)^{*}$ & $1.055(1.011,1.1)^{*}$ \\
\hline & $75-84$ & 2815 & $1.086(1.033,1.142)^{*}$ & $1.132(1.061,1.207)^{*}$ & $1.064(0.893,1.268)$ & $1.053(1.009,1.1)^{*}$ \\
\hline & $>84$ & 2307 & $1.066(1,1.137)^{*}$ & $1.134(1.044,1.232)^{*}$ & $1.174(0.999,1.39)$ & $1.072(1.012,1.134)^{*}$ \\
\hline
\end{tabular}

Cumulative RRs were lowest in the youngest age group, 65 years old or above for all pollutants. In the oldest age group, $>85$ years old, the relative risk of daily mortality was approximately $17 \%$ greater for an interquartile increase in $\mathrm{O}_{3}$, and $13 \%$ greater for an interquartile increase in $\mathrm{NO}_{2}$ (Table 3).

Given the degree of correlation between individual pollutants, two pollutant models were tested to investigate independent effects of each pollutant. Relative risk estimates remained significant for $\mathrm{CO}, \mathrm{NO}_{2}$ or $\mathrm{PM}_{2.5}$ and non-significant for $\mathrm{O}_{3}$ (Table 4). There was no significant difference between the univariable and two pollutant models based on the observed overlap of the $95 \%$ confidence intervals of the cumulative RR estimates.

\section{Discussion}

In this study, we found that on days of higher air pollution in Santiago, deaths from COVID-19 related mortality increased. There was no demonstrable difference in the effect between males and females. All measured pollutants were associated with mortality in the oldest age group, those at least 85 years old. Relative risks were greater in the oldest than in the youngest age group, those less than 65 years old. One of the greatest effects in the oldest age group was a $13.4 \%$ increase in mortality for an IQR increase in $\mathrm{NO}_{2}$. The effect of $\mathrm{O}_{3}$ was even larger at $17.4 \%$, but the lack of a significant positive association between this pollutant and mortality overall and in other age groups suggests that it might be a chance association, resulting from the age subgroup analyses. Alternatively, it is possible that the very elderly are particularly

Table 4

Pooled overall cumulative RR (95\% CI) of Covid-19 mortality associated with an interquartile range change in ambient air pollution in two-pollutant model over 7 days lag. The two-pollutant models are adjusted for ambient temperature, relative humidity and another pollutant. Values marked with an asterisk are statistically significant ( $\mathrm{p}<0.05)$.

\begin{tabular}{|c|c|c|c|c|}
\hline & \multirow[t]{2}{*}{$\mathrm{CO}$} & Pollutant & \multirow[t]{2}{*}{$\mathrm{O}_{3}$} & \multirow[t]{2}{*}{$\mathrm{PM}_{2.5}$} \\
\hline & & $\mathrm{NO}_{2}$ & & \\
\hline $\begin{array}{l}\text { Single } \\
\text { pollutant } \\
\text { model }\end{array}$ & $\begin{array}{l}\text { 1.061(1.033, } \\
1.089)^{*}\end{array}$ & $\begin{array}{l}1.067(1.032, \\
1.103)^{*}\end{array}$ & $\begin{array}{l}0.962 \\
(0.904, \\
1.025)\end{array}$ & $\begin{array}{l}\text { 1.058(1.034, } \\
1.082) *\end{array}$ \\
\hline \multicolumn{5}{|l|}{$\begin{array}{l}\text { Addition to } \\
\text { model for: }\end{array}$} \\
\hline $\mathrm{CO}$ & $\mathrm{n} / \mathrm{a}$ & $\begin{array}{l}1.03(0.982, \\
1.081)\end{array}$ & $\begin{array}{l}0.996 \\
(0.895, \\
1.108)\end{array}$ & $\begin{array}{l}1.055(1.016, \\
1.095)^{*}\end{array}$ \\
\hline $\mathrm{NO}_{2}$ & $\begin{array}{l}1.042(1.001 \\
1.084)^{*}\end{array}$ & $\mathrm{n} / \mathrm{a}$ & $\begin{array}{l}0.993 \\
(0.913 \\
1.08)\end{array}$ & $\begin{array}{l}1.066(1.033, \\
1.099) *\end{array}$ \\
\hline $\mathrm{O}_{3}$ & $\begin{array}{l}\text { 1.075(1.03, } \\
1.121)^{*}\end{array}$ & $\begin{array}{l}\text { 1.094(1.047, } \\
1.143)^{*}\end{array}$ & $\mathrm{n} / \mathrm{a}$ & $\begin{array}{l}1.043(1.015, \\
1.071) *\end{array}$ \\
\hline $\mathrm{PM}_{2.5}$ & $\begin{array}{l}\text { 1.083(1.035, } \\
1.133)^{*}\end{array}$ & $\begin{array}{l}1.09(1.044, \\
1.138)^{*}\end{array}$ & $\begin{array}{l}0.992 \\
(0.919, \\
1.071)\end{array}$ & $\mathrm{n} / \mathrm{a}$ \\
\hline
\end{tabular}

Note: $\mathrm{n} / \mathrm{a}$ - not applicable. susceptible to $\mathrm{O}_{3}$. The time series analysis of Yao et al. (2020b) addressed particulate matter but not the primary effects of $\mathrm{O}_{3}$, and other studies have reported conflicting results for $\mathrm{O}_{3}$ (Adhikari and Yin, 2020; Zhu et al., 2020).

Toxicological and empirical evidence support our findings. Air pollution was found to be an independent risk factor for respiratory and cardiac morbidity and mortality in other epidemiologic studies (Requia et al., 2018; Liu et al., 2019). Exposure to air pollution may enhance oxidative stress and inflammation (Tsai et al., 2019), especially in the presence of hypertension, obesity and diabetes, which are conditions associated with inflammation, suggesting that perhaps air pollution may worsen pulmonary and systemic inflammation caused by COVID-19. Epidemiological and animal toxicology research indicates that $\mathrm{NO}_{2}$, $\mathrm{O}_{3}$ and $\mathrm{PM}_{2.5}$ exposure increases the risk of respiratory infection (Ciencewicki and Jaspers, 2007), suggesting that exposure may increase susceptibility to SARS-CoV-2 virus. In addition to having intrinsic toxicity (Palleschi et al., 2018), particulate air pollution may possibly be a vector for transmission and diffusion of this novel coronavirus (Comunian et al., 2020).

Evidence from previous environmental health studies indicates that air pollution in Santiago has significant toxicity, but its influence on COVID-19 related mortality has not been previously assessed (Ostro et al., 1996; Cifuentes et al., 2000; Cakmak et al., 2007; Dales et al., 2020). Results from population-based studies done elsewhere provide some evidence that air pollution may increase the number of cases and fatalities from COVID-19 (Copat et al., 2020; Yao et al., 2020b).

Several studies have tested the spatial associations between COVD19 related outcomes in different cities or regions with different ambient concentrations of air pollutants (Copat et al., 2020). Yao et al. (2020b), based on a study of 49 cities in China, reported that a $10 \mu \mathrm{g} / \mathrm{m}^{3}$ increase in $\mathrm{PM}_{2.5}$ was associated with a $0.24 \%$ (95\% CI: $0.01-0.48$ ) increase in case fatality rate. The authors pointed out that confounding may occur when comparing the mortality experience between different cities if there are city-specific differences in age, urbanization/crowding, prevalence of underlying comorbidities, which are risk factors for mortality, intensity of public health infection control measures. Others have suggested that climate, and availability of medical care may be influencing factors (Coccia, 2020; Copat et al., 2020).

Compared to studies looking at spatial differences in outcomes, an advantage of our study design is that we measured short-term temporal differences in mortality in the same population and in the same geographic area, which should control for person and geographic characteristics. Findings have differed somewhat between previous studies of the temporal association between air pollution and COVID-19 related outcomes. A time series analysis in China by Zhu et al. (2020) using generalized additive models controlling for temporal trends and weather, reported that a $10 \mu \mathrm{g} / \mathrm{m}^{3}$ increase in daily $\mathrm{PM}_{2.5}, \mathrm{NO}_{2}$, and $\mathrm{O}_{3}$ was related to a $2.24 \%$ (95\% CI: $1.02-3.46), 6.94 \%(95 \%$ CI: $2.38-11.51$ ), and $4.76 \%$ (95\% CI: $1.99-7.52)$ increase in daily confirmed COVID-19 cases. Zoran et al. (2020a, 2020b) reported a positive Pearson correlation coefficient $(r=0.25)$ between daily mean $\mathrm{PM}_{2.5}$ in Milan, Italy, and the number of newly confirmed daily cases, 
but negative correlations with both total case and total deaths $(\mathrm{r}=$ -0.39 and -0.53 , respectively). It was uncertain if these tests of a linear correlation adjusted for unwanted temporal trends, day of the week or weather, and did not calculate RR of air pollution in the role of COVID-19 related deaths. A study done in Queens county, a borough of New York city, using a negative binomial model, reported statistically significant but negative associations between daily $\mathrm{PM}_{2.5}$ and both newly diagnosed COVID-19 cases and deaths (Adhikari and Yin, 2020). In this study, $\mathrm{O}_{3}$ was positively associated with new cases but negatively associated with daily deaths from COVID-19 (Adhikari and Yin, 2020). Regression model estimates for mortality using a moving average lag of 0-21 days, and adjusted for trend and weather were -0.115 (standard error or SE: 0.057) and -0.110 (SE: 0.053) for $\mathrm{PM}_{2.5}$ and $\mathrm{O}_{3}$, respectively, both significant at $\mathrm{p}<0.05$ (Adhikari and Yin, 2020). The authors questioned whether meteorological factors may have influenced their results, suggesting that decreased sunshine may possibly increase viral transmission (Adhikari and Yin, 2020). Unlike the studies of Zoran et al. (2020a, 2020b) and Adhikari and Yin (2020), our study found positive associations between mortality and exposure to both $\mathrm{NO}_{2}$ and $\mathrm{PM}_{2.5}$. Our findings are more consistent with the time series analysis of Zhu et al. (2020), which reported increased case counts related to increases in air pollution, and also with the previous spatial analysis studies that reported increased COVID-19 related mortality in regions or cities with higher air pollution.

This research is unique in studying the temporal association between COVID-19 mortality and several ambient air pollutants, and being based on data collected in the southern hemisphere, during the winter months. The daily high and low in July are approximately $16{ }^{\circ} \mathrm{C}$ and $3{ }^{\circ} \mathrm{C}$ in Santiago, Chile. Winter weather with less sunlight, drier air, and lower temperatures are conducive to virus survival (Ahlawat et al., 2020), suggesting that perhaps the COVID-19 mortality risk associated with air quality may become lower during the forthcoming summer.

Strengths and Limitations: This study used administrative databases, which provided a large number of population-based observations allowing us to study mortality. However, these data sources lacked personal information apart from age, sex, primary diagnosis and place of residence. One advantage of time series analysis is that the results should not be confounded by unknown personal factors, such as ethnicity, smoking and the use of medications. Over short periods of time the population characteristics are expected to remain stable while the influence of daily changes in air pollution is being tested. Using statistical modelling, we addressed potentially confounding time-related trends in deaths, which may be caused by day of the week or temperature. In addition, to respect individual characteristics of sectors, each was analysed separately and then results were pooled. One time-varying factor was a lockdown during the months of May, June, July and August 2020. We have no quantitative information on the adequacy of health care resources, which would be expected to change over time. However, we would not expect these factors to be confounding. To be a confounder these variables would have to be a risk factor for daily deaths, and also be associated with daily changes in air pollution concentrations. We think the latter would be unlikely. We expect significant error in estimating personal exposure to air pollution by measurements obtained from ambient monitoring. Assuming this error is random, the observed effects are likely being underestimated. A previous study done in Santiago, Chile reported correlations between personal and ambient exposure which were reasonably good with correlations of 0.64 for $\mathrm{PM}_{2.5}$, 0.38 for $\mathrm{PM}_{10}$ and 0.27 for $\mathrm{NO}_{2}$ (Rojas-Bracho et al., 2002).

\section{Conclusion}

Our study provides evidence of a significant association between acute IQR increases in $\mathrm{CO}, \mathrm{NO}_{2}$, and $\mathrm{PM}_{2.5}$ and increases of approximately $6 \%$ in the daily COVID-19 related deaths. This finding could inform public health messaging and other efforts aimed at reducing air pollution, and also possibly contribute to a reduction in the large burden of mortality from this novel coronavirus.

\section{Declaration of competing interest}

The authors declare that they have no known competing financial interests or personal relationships that could have appeared to influence the work reported in this paper.

\section{Appendix A. Supplementary data}

Supplementary data to this article can be found online at https://doi. org/10.1016/j.envres.2021.111284.

\section{Funding}

This research did not receive any specific grant from funding agencies in the public, commercial, or not-for-profit sectors.

\section{Research ethics}

The data were collected for administrative purposes, and were provided with no personal identifiers; hence, the present study was exempt from review by the Health Canada Research Ethics Board.

\section{Authors contributions}

SC, CBV, AL, SS, RM and RD contributed to study conception and design, analysis and interpretation of data, drafting the article and revising it critically for important intellectual content and final approval of the version of the article to be published.

\section{References}

Adhikari, A., Yin, J., 2020. Short-term effects of ambient ozone, $\mathrm{PM}_{2.5}$, and meteorological factors on COVID-19 confirmed cases and deaths in Queens, New York. Int. J. Environ. Res. Publ. Health 17 (11), 4047. https://doi.org/10.3390/ ijerph17114047. PMID: 32517125; PMCID: PMC7312351.

Ahlawat, A., Mishra, S.K., Birks, J.W., Costabile, F., Wiedensohler, A., 2020. Preventing airborne transmission of SARS-CoV-2 in hospitals and nursing homes. Int. J. Environ. Res. Publ. Health 17 (22), 8553.

Anderson, G., Frank, J.W., Naylor, C.D., Wodchis, W., Feng, P., 2020. Using socioeconomics to counter health disparities arising from the covid-19 pandemic. BMJ 369, m2149.

Bolano-Ortiz, T.R., Camargo-Caicedo, Y., Puliafito, S.E., Ruggeri, M.F., Bolano-Diaz, S., Pascual-Flores, R., Saturno, J., Ibarra-Espinosa, S., Mayol-Bracero, O.L., TorresDelgado, E., Cereceda-Balic, F., 2020. Spread of SARS-CoV-2 through Latin America and the Caribbean region: a look from its economic conditions, climate and air pollution indicators. Environ. Res. 191, 109938.

Cakmak, S., Dales, R.E., Vidal, C.B., 2007. Air pollution and mortality in Chile: susceptibility among the elderly. Environ. Health Perspect. 115, 524-527. https:// doi.org/10.1289/ehp.9567.

Ciencewicki, J., Jaspers, I., 2007. Air pollution and respiratory viral infection. Inhal. Toxicol. 19 (14), 1135-1146. https://doi.org/10.1080/08958370701665434.

Cifuentes, L.A., Vega, J., Kopfer, K., Lave, L.B., 2000. Effect of the fine fraction of particulate matter versus the coarse mass and other pollutants on daily mortality in Santiago, Chile. J. Air Waste Manag. Assoc. 50, 1287-1298.

Coccia, M., 2020. Factors determining the diffusion of COVID-19 and suggested strategy to prevent future accelerated viral infectivity similar to COVID. Sci. Total Environ. 729, 138474. https://doi.org/10.1016/j.scitotenv.2020.138474.

Comunian, S., Dongo, D., Milani, C., Palestini, P., 2020. Air pollution and covid-19: the role of particulate matter in the spread and increase of covid-19's morbidity and mortality. Int. J. Environ. Res. Publ. Health 17 (12), 4487. https://doi.org/10.3390/ ijerph17124487.

Copat, C., Cristaldi, A., Fiore, M., et al., 2020. The role of air pollution ( $\mathrm{PM}$ and $\left.\mathrm{NO}_{2}\right)$ in COVID-19 spread and lethality: a systematic review. Environ. Res. 191, 110129. https://doi.org/10.1016/j.envres.2020.110129.

Copiello, S., Grillenzoni, C., 2020. The spread of 2019-nCoV in China was primarily driven by population density. Comment on "Association between short-term exposure to air pollution and COVID-19 infection: evidence from China” by Zhu et al. Sci. Total Environ. 744, 141028. https://doi.org/10.1016/j.scitotenv.2020.141028.

Dales, R., Blanco-Vidal, C., Cakmak, S., 2020. The association between air pollution and hospitalization of patients with idiopathic pulmonary fibrosis in Chile: a daily time series analysis. Chest 158 (2), 630-636. https://doi.org/10.1016/j. chest.2020.02.017.

DerSimonian, R., Nan, L., 1986. Meta-analysis in clinical trials. Contr. Clin. Trials 7 (3). Elsevier: $177-88$. 
Fattorini, D., Regoli, F., 2020. Role of the chronic air pollution levels in the COVID-19 outbreak risk in Italy. Environ. Pollut. 264, 114732.

Health Canada, 2019. Health impacts of air pollution in Canada. Estimates of morbidity and premature mortality outcomes. http://publications.gc.ca/collections/colle ction 2019/sc-hc/H144-51-2019-eng.pdf. (Accessed 11 September 2020).

Jorquera, H., Orrego, G., Castro, J., Vesovic, V., 2004. Trends in air quality and population exposure in Santiago, Chile, 1989-2001. Int. J. Environ. Pollut. 22 https://doi.org/10.1504/IJEP.2004.005684.

Kavouras, I.G., Koutrakis, P., Cereceda-Balic, F., Oyola, P., 2001. Source apportionment of PM(10) and (PM2.5) in five Chilean cities using factor analysis. J. Air Waste Manag. Assoc. 51 (3), 451-464. https://doi.org/10.1080/ 10473289.2001 .10464273$.

Liu, C., Chen, R., Sera, F., et al., 2019. Ambient particulate air pollution and daily mortality in 652 cities. N. Engl. J. Med. 381, 705-715. https://doi.org/10.1056/ NEJMoa1817364.

Noor, F.M., Islam, M., 2020. Prevalence and associated risk factors of mortality among COVID-19 patients: a meta-analysis. J. Community Health 45, 1270-1282.

Ostro, B., Sanchez, J.M., Aranda, C., Eskeland, G.S., 1996. Air pollution and mortality: results from a study of Santiago, Chile. J. Expo. Anal. Environ. Epidemiol. 6, 97-114.

Palleschi, S., Rossi, B., Armiento, G., Montereali, M.R., Nardi, E., Tagliani, S.M., Inglessis, M., Gianfagna, A., Silvestroni, L., 2018. Toxicity of the readily leachable fraction of urban PM2.5 to human lung epithelial cells: role of soluble metals. Chemosphere 196, 35-44.

Requia, W.J., Adams, M.D., Arain, A., Papatheodorou, S., Koutrakis, P., Mahmoud, M., 2018. Global association of air pollution and cardiorespiratory diseases: a systematic review, meta-analysis, and investigation of modified variables. Am. J. Publ. Health 108 (S2), S123-S130. https://doi.org/10.2105/AJPH.2017.303839.

Rojas-Bracho, L., Suh, H.H., Oyola, P., Koutrakis, P., 2002. Measurements of children's exposures to particles and nitrogen dioxide in Santiago, Chile. Sci. Total Environ. 287, 249-264.

Samoli, E., Analitis, A., Touloumi, G., Schwartz, J., Anderson, H.R., Sunyer, J., Bisanti, L., Zmirou, D., Vonk, J.M., Pekkanen, J., Goodman, P., Paldy, A., Schindler, C., Katsouyanni, K., 2005. Estimating the exposure-response relationships between particulate matter and mortality within the APHEA multicity project. Environ. Health Perspect. 113 (1), 88-95. https://doi.org/10.1289/ehp.7387. Erratum in: Environ Health Perspect. 2005 May;113(5):A297. PMID: 15626653; PMCID: PMC1253715.

Santiago Province in Chile, 2020. Census Data. https://www.citypopulation.de/en/chi le/mun/admin/131_santiago/. (Accessed 10 November 2020).
Schwartz, J., 2000. The distributed lag between air pollution and daily deaths. Epidemiology 11 (3), 320-326.

Simonnet, A., Chetboun, M., Poissy, J., Raverdy, V., Noulette, J., Duhamel, A., Labreuche, J., Mathieu, D., Pattou, F., Jourdain, M., LICORN and the Lille COVID-19 and Obesity study group, 2020. High prevalence of obesity in severe acute respiratory syndrome coronavirus-2 (SARS-CoV-2) requiring invasive mechanical ventilation. Obesity 28 (7), 1195-1199. https://doi.org/10.1002/oby.22831.

Tsai, D.-H., Riediker, M., Berchet, A., Paccaud, F., Waeber, G., Vollenweider, P. Bochu, M., 2019. Effects of short- and long-term exposures to particulate matter on inflammatory marker levels in the general population. Environ. Sci. Pollut. Res. 26, 19697-19704.

World Health Organization, 2021. https://covid19.who.int/. (Accessed 15 October 2020).

World Health Organization (WHO), 2019. International Statistical Classification of Diseases and Related Health Problems $10^{\text {th }}$ Revision. https://icd.who.int/browse10/ 2019/en. (Accessed 10 November 2020).

World Health Organization, 2016. WHO's Urban Ambient Air Pollution Database-Update 2016 Version 0.2. Geneva. (Accessed 15 October 2020).

Wu, Z., McGoogan, J.M., 2020. Characteristics of and important lessons from the coronavirus disease 2019 (COVID-19) outbreak in China: summary of a report of 72 314 cases from the Chinese Center for Disease Control and Prevention. J. Am. Med. Assoc. 323 (13), 1239-1242. https://doi.org/10.1001/jama.2020.2648.

Yao, Y., Pan, J., Liu, Z., Meng, X., Wang, W., 2020a. Temporal association between particulate matter pollution and case fatality rate of COVID-19. Environ. Res. 189, 109941.

Yao, Y., Pan, J., Wang, W., et al., 2020b. Association of particulate matter pollution and case fatality rate of COVID-19 in 49 Chinese cities. Sci. Total Environ. 741, 140396. https://doi.org/10.1016/j.scitotenv.2020.140396.

Zhu, Y., Xie, J., Huang, F., Cao, L.A., 2020. Association between short-term exposure to air pollution and COVID-19 infection: evidence from China. Sci. Total Environ. 727, 138704.

Zoran, M.A., Savastru, R.S., Savastru, D.M., Tautan, M.N., 2020a. Assessing the relationship between ground levels of ozone (O3) and nitrogen dioxide (NO2) with coronavirus (COVID-19) in Milan, Italy. Sci. Total Environ. 740, 140005.

Zoran, M.A., Savastru, R.S., Savastru, D.M., Tautan, M.N., 2020b. Assessing the relationship between surface levels of PM2.5 and PM10 particulate matter impact on COVID-19 in Milan, Italy. Sci. Total Environ. 738, 139825. 